\title{
Effects of industrial wastewater reuse for crop production: A case study in Tejgaon metropolitan area of Dhaka, Bangladesh
}

\author{
S. Roy ${ }^{1^{*}}$, L. N. Banna ${ }^{2}$, S. A. Mamun ${ }^{3}$ and M. A. Farukh ${ }^{4}$ \\ ${ }^{2,3}$ Department of Environmental Science and Resource Management, Mawlana Bhashani Science and Technology \\ University, Tangail-1902, Bangladesh and ${ }^{1,4}$ Department of Environmental Science, Bangladesh Agricultural \\ University, Mymensingh-2202, Bangladesh, `E-mail: Sr.esrm_06@yahoo.com
}

\begin{abstract}
This study was carried out to identify the benefits, adverse effects, social acceptance and a long term impacts of industrial wastewater reuse in the Tejgaon metropolitan area of Dhaka city. Questionnaire surveys were conducted in the exposed and control sites to collect data on the farmers' perception and responses regarding agricultural, economic, social and environmental health issues. The most important benefits of wastewater reuse have been found as the availability of wastewater over all seasons and economic return from reduced chemical fertilizer requirement in vegetable field. The potential risks of wastewater reuse have been found as the increased insect attacks, diseases and excessive weed problem. Farmer mentioned that long term exposure of this water stimulates crop growth rapidly but it reduces grain production dramatically. Sometimes excess wastewater used for irrigation or short-term water logging in the area eventually leads to crop damage. Interviews with the key factors indicate that a long term institutional arrangement for sustainable reuse of wastewater is not beneficial in the region.
\end{abstract}

Keywords: Pest, Waste water, Crop, Tejgaon

\section{Introduction}

The Tejgaon metropolitan area is one of the highly concentrated industrial areas of Dhaka city. There are about 300 types of industries in Dhaka city where most of them are found in this area. Tejgaon industrial area alone dispose about $12,000 \mathrm{~m}^{3}$ untreated industrial wastes per day, which consists variety of industrial units like soap, dyeing, pharmaceutical, metals etc (Annual bulletin Tejgaon Upazila, 2003). The wastes of this industrial area are directly discharged in to the Begunbari canal which carries the wastes through the Narai canal to the Balu River and ultimately flows on Sitalakhya River. Thus Balu River and the canal system especially Begunbari canal and Narai canal are the most polluted areas in Dhaka East (DoE, 2001). Today about 119676 people from 168 villages lead their life compromising with potential threats from these polluted water sources. This situation related to water quality is not only important for the human being, but also for the danger of diffusion of toxic substances into other ecosystems. Today, nearly 40 percent of the world's food supply is grown under irrigation, and a wide variety of industrial processes depend on water (BCAS, 2000). It has recently been estimated that about 20 million hectares of land are irrigated with treated, partially treated, diluted and untreated wastewater in developing countries (Scott et al., 2004 and Keraita et al., 2008).

Wastewater may supply organic matter and mineral nutrients to soil that are beneficial to crop production, and reduce the cost of fertilizer application (Van der Hoek et al., 2002).Almost all the members of the peasantry society consider waste water to use in irrigation but wastewater in agriculture has both positive and negative potential impacts on crop production, public health, soil resources and ecosystems (Hussain et al., 2002; Scott et al., 2004). Urban wastewater may contain hazardous substances including higher trace elements, heavy metals and pathogenic micro-organisms (Siebe and Cifuentes, 1995).

It results in adverse affects on agriculture, agricultural production and consumers of vegetables and neighboring communities, often leading to various types of disease. However, the magnitude of these adverse effects varies from region to region and from community to community depending on the volume and source of the wastewater, and treatment before use as well as the management of the wastewater both at its source and at the level of farm usage (Drechsel et al., 2010).

The main objectives of this paper were (i) to observe the effects of industrial waste water irrigation on crop yield, and (ii) to quantify the benefits and losses by using waste water in agricultural land of Tejgaon metropolitan area. 


\section{Materials and Methods}

\section{Study area}

Tejgaon metropolitan area is one of the exceptional areas of capital Dhaka city where waste water from Tejgaon industrial facilities are mostly used for irrigation(Annual bulletin Tejgaon Upazila, 2003). This area is located from $23.75^{\circ} \mathrm{N}$ to $89.39^{\circ} \mathrm{E}$ that occupies approximately $8.75 \mathrm{~km}^{2}$ (Annual bulletin Tejgaon Upazila, 2003). There are 42,445 farmers from 32 blocks out of 40 blocks or 17 unions, developed life belongs to the Begunbari canal, Narai canel and Balu River $(20 \mathrm{~km})$ (Table 1) (Fig. 1). Total agricultural land 7294 hectors (Annual bulletin Tejgaon Upazila, 2003). Average temperature is nearly $24.94{ }^{\circ} \mathrm{C}$ in Boro/ winter season and $30.23{ }^{\circ} \mathrm{C}$ in kharip/ summer season. Mean annual rainfall $200 \mathrm{~mm}$ (Annual bulletin Tejgaon Upazila, 2003).

Table 1. Morphological information of the study area

\begin{tabular}{|c|c|c|}
\hline \multicolumn{2}{|c|}{ Morphological information } & Description \\
\hline \multirow[t]{2}{*}{ Study area } & Expose sites & $\begin{array}{l}\text { Total } 27 \text { blocks i.e. Dubadia, Gabindapur, Mausaied, Dakahinkhan, } \\
\text { Fayadabad, Kaular, Boura, Harirampur, Digun, Chandalbhog, Bailjuri, } \\
\text { Beraid, Dhaur, Talna, Dumni, Nasirabad, Trimohoni, Dakahingau, Manikdia, } \\
\text { Damra, Amulia, Matuail, Sarulia, Dogair, Sultanganj, Satarkul and vatara. }\end{array}$ \\
\hline & Control sites & Total 5 blocks i.e. Uttar khan, moinartec, ujampur, kachkura and Bauthar. \\
\hline \multicolumn{2}{|c|}{$\begin{array}{l}\text { Out of study area (Agricultural } \\
\text { practice is not significant) }\end{array}$} & $\begin{array}{l}\text { Remaining } 8 \text { Blocks i.e. Manda, Shampur, Dania, Badda, Jatrabari, } \\
\text { Dholairpar, Jurain. }\end{array}$ \\
\hline \multicolumn{2}{|c|}{$\mathrm{AEZ}$} & Young Brahmaputra and Jamuna Flood Plain. \\
\hline \multicolumn{2}{|c|}{ General Soil Type } & Medium high land \\
\hline \multicolumn{2}{|c|}{ Major vegetation } & Rice and other vegetation crop grown year round. \\
\hline
\end{tabular}

Source: Annual bulletin Tejgaon Upazila (2003)

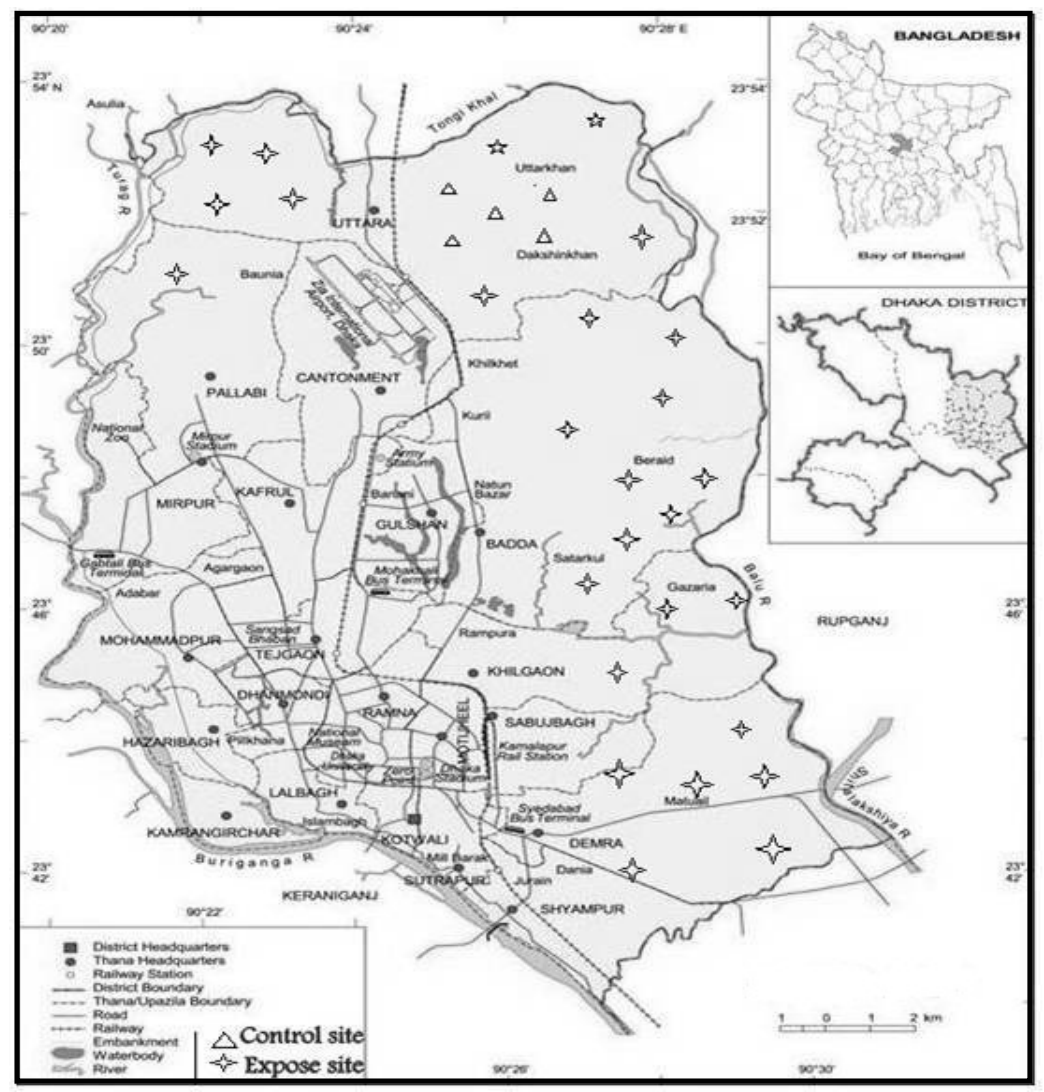

Fig. 1. Map showing the study area at Tejgaon metropolitan area 


\section{Data collection and analysis}

Opportunity and adverse impacts of wastewater were evaluated by applying an integrated research method. Questionnaire survey with different techniques was applied to complete the study. Exposed and control site approach were applied in this current study. Only some part of Uttar khan union was identified as a control site (site where clean water source is used for agricultural purposes by the farmers) and remaining most of the part is wastewater exposed site where farmers use wastewater extensively for crop irrigation (Figure 1). The data were collected by reconnaissance filed survey, questionnaire survey and the institutional survey and also by the help of published statistical data from different books, articles and organizations such as Upazila Agriculture Extension Office. A total of 480 respondents were randomly selected for questionnaire survey. Each respondent was selected from individual farmers' family and 15 respondents were randomly selected from each block for well representation of whole study area. The survey was carried out during the 2011-2012 Boro season. Before the questionnaire survey at least 10 sample questionnaires were pre-tasted. A non structural institutional questionnaire survey was also conducted to evaluate the feasibility of an institution for long term benefits and impacts of wastewater reuse.

The collected data were than complied and analyzed using analytical software Statistical Package for Social Sciences (SPSS) and Microsoft Excel.

\section{Results and Discussion}

\section{Profile of the respondents}

In Tejgaon metropolitan area irrigation using wastewater from Balu River and Narai canal has been practiced by the peri urban farming community since 1986 (Annual bulletin Tejgaon Upazila, 2003). Increasing with rapid industrialization the water is becoming more polluted day by day and the farming community and local community do not face any legal restriction of using polluted water. Among the 480 respondents $84.38 \%$ farmers used irrigation water from exposed sites and $15.63 \%$ from controlled sites. This variation was observed due to having only 5 blocks of 32 blocks in control sites and the remaining 27 blocks in expose sites. Most of the respondents' (34.6 percent) age range lies in 21-40 years and the majority of the participants (46.1\%) were illiterate. It is revealed from the study that a large number of the respondents were lying between 1000 to 5000 tk/month (42.2 percent) and 6000-10000 tk/month economical condition (40.5 percent) whereas only 17.3 percent of respondents were found who were living above the poverty line. Most of the farmers (92\%) in the study area liked to use the Narai canal and Balu River as are waste water sources because of the least water and fertilizer cost, and the scarcity of groundwater for their crops (Table 2). According to respondents' untreated industrial waste (51.1\%) along with sewerage waste disposal (24.2\%) are mainly responsible for polluting the river water which is certainly considered by the common masses (85\%) to be waste water in case of irrigation (Table 2). About $77.78 \%$ farmers in exposed sites reported that they could keep the fertilizer cost to minimum due to using wastewater whereas 84 percent of farmers in controlled site reported that their fertilizer cost increased (Table 3).

Table 2. Perception of localities about the River and canal systems in this area and irrigation system

\begin{tabular}{|l|l|c|}
\hline Indicators & Variable & Percent (\%) \\
\hline Causes of Narai canal and Balu River pollution & Industrial pollution & 51.1 \\
& Waste oil from launch & 20.6 \\
& Sewerage sludge & 24.2 \\
& Agricultural runoff & 4.1 \\
\hline $\begin{array}{l}\text { People's perception about the water quality of Balu } \\
\text { River \& Narai canal }\end{array}$ & It becomes waste water & 85 \\
\hline Major utility of this river water for this locality & Irrigation (= yes) & 92 \\
\hline Why people use river water for irrigation purposes? & Washing, bathing or both (= yes) & 35 \\
& Low irrigation cost (=yes) & 66 \\
& Easily assessable round the year (=yes) & 70 \\
& Reduce fertilizer cost (=yes) & 77.78 \\
\hline
\end{tabular}


Many of them (46.25\%) said that this waste water was not good for crop production but majority of them $(79.7 \%)$ used waste water and ware saving the fertilizer cost. On the other hand $53.75 \%$ farmers commented that using of wastewater was reliable for their crops (Table 3). But what's the mystery behinds this argument and crop cultivation system ?

As wastewater is available and sufficient round the year in the exposed sites vegetable cropping intensity is high in comparison to the controlled sites where fresh water is used. In this area vegetables become healthier within a short period of time due to the presence of higher nutrients in the soil but it also results of reducing in grain production. Its results less rice production are being found day by day in the exposed sites. About 60 percent farmers of the exposed sites prefer to produce vegetables due to this environmental condition (Table 3).

On the other hand many of them did not get good benefits in exposed sites from grain production after adopting various types of technology. They realized that their land was becoming degrading day by day.

Table 3. Respondent's perception about efficiency and sources of different irrigation water (Cross tabulation within Perceptions about waste water use in agriculture, sources of irrigated water and Fertilizer cost)

\begin{tabular}{|c|c|c|c|c|c|c|c|c|}
\hline \multirow{2}{*}{\multicolumn{2}{|c|}{$\begin{array}{l}\text { Perceptions about } \\
\text { waste water use in } \\
\text { agriculture }\end{array}$}} & \multicolumn{3}{|c|}{$\begin{array}{l}\text { Source of water } \\
\text { for irrigation purposes (\%) }\end{array}$} & & \multicolumn{3}{|c|}{ Fertilizer cost (\%) } \\
\hline & & source & $\%$ & $\mathrm{~N}$ & & Increased & Decreased & No change \\
\hline \multirow{6}{*}{\multicolumn{2}{|c|}{$\begin{array}{l}\text { Good for } \\
\text { agriculture } \\
(53.75 \%)\end{array}$}} & \multirow{2}{*}{$\begin{array}{l}\text { Ground } \\
\text { water }\end{array}$} & \multirow[t]{2}{*}{11.6} & \multirow[t]{2}{*}{10} & $\mathrm{~N}$ & 8 & 0 & 2 \\
\hline & & & & & $\begin{array}{l}\text { \% within ground water user for } \\
\text { irrigation purposes }\end{array}$ & 80 & 0 & 20 \\
\hline & & \multirow[t]{2}{*}{ waste water } & \multirow[t]{2}{*}{88.4} & \multirow[t]{2}{*}{76} & $\mathrm{~N}$ & 13 & 58 & 5 \\
\hline & & & & & $\begin{array}{l}\% \text { within waste water } \\
\text { for irrigation purposes }\end{array}$ & 17.1 & 76.3 & 6.6 \\
\hline & & \multirow[t]{2}{*}{ Total } & \multirow[t]{2}{*}{100} & \multirow[t]{2}{*}{86} & $\mathrm{~N}$ & 21 & 58 & 7 \\
\hline & & & & & $\begin{array}{l}\text { \% within source of water } \\
\text { for irrigation purposes }\end{array}$ & 24.4 & 67.5 & 8.1 \\
\hline \multirow{6}{*}{\multicolumn{2}{|c|}{$\begin{array}{l}\text { Not good for } \\
\text { agriculture } \\
(46.25 \%)\end{array}$}} & \multirow{2}{*}{$\begin{array}{l}\text { Ground } \\
\text { water }\end{array}$} & \multirow[t]{2}{*}{20.3} & \multirow[t]{2}{*}{15} & $\mathrm{~N}$ & 13 & 0 & 2 \\
\hline & & & & & $\begin{array}{l}\% \text { within ground water } \\
\text { for irrigation purposes }\end{array}$ & 86.7 & 0 & 13.3 \\
\hline & & \multirow[t]{2}{*}{ waste water } & \multirow[t]{2}{*}{79.7} & \multirow[t]{2}{*}{59} & $\mathrm{~N}$ & 7 & 47 & 5 \\
\hline & & & & & $\begin{array}{l}\% \text { within waste water } \\
\text { for irrigation purposes }\end{array}$ & 11.8 & 79.7 & 8.5 \\
\hline & & \multirow[t]{2}{*}{ Total } & \multirow[t]{2}{*}{100} & \multirow[t]{2}{*}{74} & $n$ & 20 & 47 & 7 \\
\hline & & & & & $\begin{array}{l}\text { \% within source of water } \\
\text { for irrigation purposes }\end{array}$ & 27.0 & 63.5 & 9.5 \\
\hline
\end{tabular}

\section{Influence on nutrients uptake and fertilizer application}

Wastewater contains significant amount of nutrients ( $N, P, K)$ for crops. According to the farm owners, in exposed sites they can save about $115-170 \mathrm{~kg}$ of Urea (Nitrogen fertilizer), $47-100 \mathrm{~kg}$ of TSP, $33-40 \mathrm{~kg}$ of MP and 40-44 kg of Zipsum per hectare of Boro, Ropa amon and vegetable crop production. The highest rate of fertilizer saving i.e. BDT $6400 \mathrm{tk} /$ ha was observed for vegetable cultivation. On the other hand the rate of fertilizer application has been found as much higher in the control sites rather than the exposed sites (Table 4). It can be explained as; wastewater is rich in nutrient and saves a good amount of fertilizer.

Table 4. Scenario of required nutrient within ground water and waste water irrigation site

\begin{tabular}{|c|c|c|c|c|c|c|c|c|c|c|c|c|c|}
\hline \multirow[t]{2}{*}{ Crops } & \multicolumn{3}{|c|}{ Urea kg/ha } & \multicolumn{3}{|c|}{ TSP kg/ha } & \multicolumn{3}{|c|}{ MP kg/ha } & \multicolumn{3}{|c|}{ Zipsum } & \multirow{2}{*}{$\begin{array}{c}\text { Total } \\
\text { cost } \\
\text { saving } \\
\text { BDT/ha }\end{array}$} \\
\hline & GW & WW & Save & GW & WW & Save & GW & WW & Save & GW & WW & Save & \\
\hline Boro ufshe & 250 & 130 & 120 & 170 & 123 & 47 & 100 & 67 & 33 & 100 & 56 & 44 & 4237 \\
\hline Ropa amon ufshe & 225 & 110 & 115 & 150 & 90 & 60 & 75 & 35 & 40 & 90 & 50 & 40 & 4500 \\
\hline Vegetable & 200 & 30 & 170 & 150 & 50 & 100 & 65 & 25 & 40 & 52 & 12 & 40 & 6400 \\
\hline
\end{tabular}

Note: Price of Fertilizer: Urea= BDT 20/kg, TSP= BDT 22 /kg, MP = BDT 15/kg, Zipsum= 7/kg (Annual bulletin Tejgaon Upazila, 2012) *GW means Ground Water sites, WW means Waste Water sites 
Van der Hoek et al. (2002) reported that, untreated wastewater increases the crop production and also minimizes fertilizer and water cost. On the other hand Flores et al. (1992) observed that untreated waste water may contain various types of heavy metal trace element and pathogens which may creates great harms in plant flowering, crop yield, crop disease and other growth stages of plant. On contrast accumulation or use of over dose $\mathrm{N}_{2}$ in crop land decreases the crop reaches maturity and ultimately its results lower grain crop production. Similar characters were found in this study.

It was found that, in the exposed sites vegetable production and economic returns were always higher than that of controlled sites (Table 4 \&5). Economic benefits were found due to higher agricultural production which is as high as up to BDT 61,600/ha from tomato production and up to BDT 33,200/ha for vegetable of palong production (Table 5).

Table 5. Yield, economic benefits or losses of exposed sites with respect to control site and farmers' perception

\begin{tabular}{|c|c|c|c|c|c|c|c|c|c|}
\hline \multirow[t]{2}{*}{ Seasonal verity } & \multirow[t]{2}{*}{ Verity name } & \multicolumn{3}{|c|}{$\begin{array}{l}\text { Average Production } \\
\text { Tons/ ha(2011) }\end{array}$} & \multirow{2}{*}{$\begin{array}{l}\text { Market } \\
\text { Price } \\
\text { /kg }\end{array}$} & \multirow{2}{*}{$\begin{array}{c}\text { Economic } \\
\text { Benefit(+)/ } \\
\text { loss }(-) \\
(\text { BDT })\end{array}$} & \multirow{2}{*}{$\begin{array}{c}\text { Fertilizer } \\
\text { Cost } \\
\text { Saving } \\
\text { /ha }\end{array}$} & \multirow{2}{*}{$\begin{array}{l}\text { Extra Labor } \\
\text { cost for pest, } \\
\text { weed }\end{array}$} & \multirow{2}{*}{$\begin{array}{c}\text { Cumulative } \\
\text { Economic } \\
\text { Benefit/ loss } \\
\text { BDT/ha }\end{array}$} \\
\hline & & WW & $\mathrm{FW}$ & WW-FW & & & & & \\
\hline \multirow[t]{2}{*}{ Boro ufshe rice } & BRI-28 & 3.6 & 4.8 & -1.2 & 26 & $-31,200$ & \multirow[t]{2}{*}{$+4,237$} & \multirow[t]{2}{*}{-800} & $-27,763$ \\
\hline & BRI-29 & 3.7 & 4.9 & -1.0 & 24 & $-24,000$ & & & $-20,563$ \\
\hline \multirow{2}{*}{$\begin{array}{l}\text { Ropa amon } \\
\text { ufshe rice }\end{array}$} & BRI-11 & 3.4 & 3.2 & +0.2 & 22 & $+4,400$ & \multirow[t]{2}{*}{$+4,500$} & \multirow[t]{2}{*}{-600} & $+8,300$ \\
\hline & BRI-30 & 3.6 & 3.1 & +0.5 & 22 & $+11,000$ & & & $+14,900$ \\
\hline \multirow[t]{2}{*}{ Vegetable } & Tomato & 20 & 17.8 & +2.2 & 28 & $+61,600$ & \multirow[t]{2}{*}{$+6,400$} & \multirow[t]{2}{*}{-800} & $+67,200$ \\
\hline & Palong shag & 8 & 5.6 & +2.3 & 12 & $+27,600$ & & & $+33,200$ \\
\hline
\end{tabular}

These farmers commented that they liked to grow vegetables because when grown with wastewater, vegetables become healthier, colored, and attractive therefore easy to sell in the market even from field. But this result is not similar for grain crop production. Crop becomes healthier quickly but before it become mature it is dropped thus grain does not come as they think. It is observed in the exposed sites that Boro crop production brings economic losses and it is up to BTD 27,763/ ha for BRI-28 but Ropa amon brings some little benefits that is BDT 14,900/ ha for BRI-30 due to increasing with volume of water in monsoon, excessive amount of pollutant become diluted. This result explains that why larger portion of the farmers in the exposed sites liked to grow vegetables in their field.

\section{Crop diseases and pest}

As observed, incidences of more crop diseases and pest are one of the main problems of wastewater reusing in crop fields. It is observed from the study that in exposed sites $71.80 \%$ farmers have to face serious crop diseases during crop cultivation and $74.10 \%$ farmers commented that pest has increased drastically than that of fresh water sites (Figure 2). And its impacts become more hazardous when summer season come.

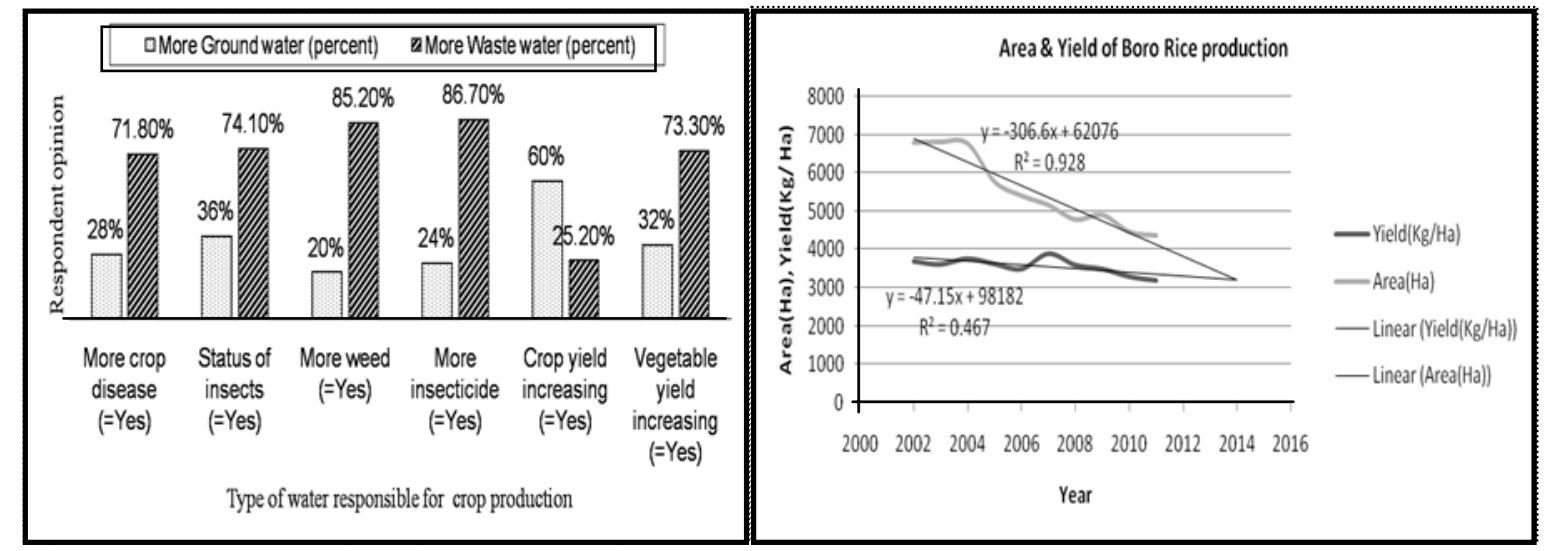

Fig. 2. Incidents of agricultural hazards informed by the farmers (Left). Area and yield of Boro Rice production in Tejgaon metropolitan area (Right).

Source: Survey data \& Annual bulletin Tejgaon metropolitan area (2002-2011). 
Most of the respondents (86.70\%) who uses this river water as waste water for irrigation purposes reported that they are having too much weed problems in their fields which are costing them an excessive amount of labor cost. In contrast, in ground water site these problems are comparatively lower than exposed sites.

It is observed from the study that $74.8 \%$ farmers in exposed sites said that crop yield reduced drastically than past compared to controlled sites for what people are now diverting into other professions and it results less crop yield and its area both are reducing day by day (Figure 2).

\section{Conclusion}

The present study suggests that, farmer's first impression when goes towards the fertilizer cost savings but many of them have no idea about the toxicity of waste water irrigation and how it can bring about their economic losses. The waste water of the area increased pesticide cost and potential impact of weed problem. It increased the growth of crop but reduced the grain yields and delayed its maturities. Waste water also increased crop diseases and soil pollution. However, the waste water reuse does not bring green environment and well socioeconomic condition and so we should have to focus on a sustainable management procedure.

\section{References}

Annual bulletin Tejgaon Upazila. 2002-2011. Upazila agriculture extension office, (2002-2012), 6,7,5,13,15,9,7,5,5,6,6 pp

BCAS. 2000. Pollution Study, Management of Aquatic Ecosystem through Community Husbandry (MACH), Dhaka, Bangladesh.

DoE, 2001. The General over view of pollution status of Rivers of Bangladesh, Department of Environment. Dhaka, Bangladesh.

Drechsel, P., Scott, C.A., Raschid-Sally, L., Redwood, M. and Bahri, A. 2010. Wastewater irrigation and health: Assessing and mitigating risk in low-income countries. Earthscan, London: The International Water Management Institute and the International Development Research Centre.

Flores, D.L., Herna, S.G., Alcala, M.R. and Maples, V.M. 1992. Total contents of cadmium, copper, manganese and zinc in agricultural soils irrigated with wastewater from Hidalgo. Mexico, Rev. Int. Contam. Ambient, 8, 37- 46.

Hussain, I., Raschid, L., Hanjra, M.A., Marikar, F. and van der Hoek, W. 2002. Wastewater use in agriculture: review of impacts and methodological issues in valuing impacts (with an extended list of bibliographical references). Working Paper 37 , International Water Management Institute (IWMI), Colombo, Sri Lanka.

Keraita, B., Jimenez, B. and Drechsel, P. 2008. Extent and implications of agricultural reuse of untreated, partly treated and diluted wastewater in developing countries. CAB Reviews: Perspectives in Agriculture, Veterinary Science, Nutrition and Natural Resources 3: 15.

Scott, C.A., Faruqui, N.I. and Raschid-Sally L. 2004. Wastewater Use in Irrigated Agriculture: Confronting the Livelihood and Environmental Realities. Wallingford, UK: CABI.

Siebe, C. and Cifuentes E. 1995. Environmental impact of wastewater irrigation in central Mexico: an overview. International Journal of Environmental Health Research. Elsevier Science Ltd, 5: 161-173.

Van der Hoek, Hassan, W., Ensink, U.M., Feenstra, J.H.J., Raschid, S., Munir, S.L., Aslam, S., Ali, R., Hussain, N.R. and Matsuno,Y. 2002. Urban Wastewater: A Valuable Resource for Agriculture. International Water Management Institute, Research Report 63, Colombo, Sri Lanka. 